\title{
LUDWIG VON MISES AS CURRENCY SCHOOL FREE BANKER
}

\author{
JOSEPH T. SALERNO*
}

Resumen: El centenario de la publicación de la primera edición alemana de The Theory of Money and Credit de Ludwig von Mises, ofrece una excelente oportunidad para reconsiderar una controversia duradera dentro de la economía austriaca moderna. Ésta gira en torno a la cuestión de si Ludwig von Mises apoyó una banca de reserva en oro del 100\% impuesta por ley o una banca libre basada en el oro como su sistema monetario ideal. En este trabajo, sugiero que este debate está fundamentalmente mal enfocado y confunde medios y fines. Sostengo que Mises defendió un sistema de banca libre como el medio más adecuado para lograr el objetivo de suprimir la emisión de dinero fiduciario en forma de billetes bancarios y depósitos a la vista. Este objetivo fue inicialmente enunciado por la Escuela Monetaria del siglo XIX e incorporado en su famoso "principio monetario.» Mi tesis es que Mises fue proponente del principio monetario y de la banca libre, y que observó a esta última como el medio indispensable para regular el comportamiento de la oferta monetaria conforme al primero. En la defensa de esta tesis, trato de replantear el debate sobre las ideas monetarias de Mises de una forma más relevante y contribuir de este modo a su resolución.

Palabras clave: Mises, Escuela Monetaria, Banca Libre, Principio Monetario, Equilibrio Monetario.

Clasificación JEL: B31, B53, E42, E52.

Abstract: The centennial of the publication of the first German edition of Ludwig von Mises's The Theory of Money and Credit offers an excellent opportunity to reconsider a long-standing controversy within modern Austrian economics. This revolves around the question of whether Ludwig von Mises favored 100-percent gold reserve banking imposed by law or free banking based on gold as the ideal monetary system. In this paper, I suggest that this

* Lubin School of Business. Pace University. New York. jsalerno@pace.edu 
debate is fundamentally misfocused and conflates means and ends. I argue that Mises advocated free banking as the most suitable means for achieving the goal of suppressing the issue of fiduciary media, in the form of bank notes and demand deposits. This goal was first enunciated by the nineteenth-century British currency school and embodied in its famous «currency principle.» My thesis is that Mises was a proponent of both the currency principle and free banking and that he viewed the latter as the indispensable means to regulate the behavior of the money supply according to the former. In defending this thesis, I seek to reframe the debate on Mises's monetary views in a more meaningful way and to contribute to its resolution.

Key words: Mises, Currency School, Free Banking, Currency Principle, Monetary Equilibrium.

JEL Classification: B31, B53, E42, E52.

INTRODUCTION

The centennial of the publication of the first German edition of Ludwig von Mises's The Theory of Money and Credit (1980) ${ }^{1}$ offers an excellent opportunity to address a long-standing controversy that has beset Austrian monetary economics for the past three decades. The controversy revolves around the question of whether Ludwig von Mises favored 100-percent gold reserve banking imposed by law or free banking based on gold as the ideal monetary system. There exists sufficient ambivalence in Mises's writings on this point to provide support to the claims of the proponents of both positions. I suggest that this debate is fundamentally misfocused and conflates means and ends. As I argue in this paper, Mises advocated free banking as the most suitable means for achieving the goal of completely suppressing the issue of additional fiduciary media, that is, bank notes and deposits unbacked by gold. In effect, Mises looked forward to a marginal

1 The English edition was translated from the second German edition published in 1924 (Mises 1924). 
100-percent reserve ratio on the issue of bank notes and deposits as the outcome of the operation of a free banking regime.

The framing of the debate in terms of Mises's stance on free banking versus 100-percent reserves obscures a much deeper issuedividing Austriansthat pertains to Mises theoretical perspective on the relationship between money and the banking system. Throughout his body of work on monetary economics, Mises steadfastly proclaimed his adherence to the basic doctrines of the mid-nineteenth century British currency school and, in fact, upheld its "currency principle» as the essence of his own conception of sound money. According to the currency principle, the ideal monetary system was one in which the supply of money, comprising circulating gold plus bank notes and deposits redeemable in gold, should be made to behave exactly like the supply of a pure gold money.Lately, some members of the modern free banking school, as it has come to be called, have denied that Mises was a follower of the currency school or that his vision of sound money was defined by the currency principle. The free bankers base their claim on the fact that Mises was a vigorous proponent of free banking. In contrast, they point out, most prominent members of the original currency school opposed free banking and favored a central bank as the means to enforce the currency principle on the banking system. Thus, the free bankers conclude that Mises, as a free banker, must have supported their «monetary equilibrium» principle, according to which the supply of money should adjust to offset fluctuations in the demand for money and would automatically do so under a free banking regime.

The argument of this paper is twofold. First, I contend that Mises was indeed an admirer and follower of the currency school, and that he deliberately attempted to revise and improve its doctrine and apply it to contemporary conditions. Second I review Mises's strong support for a free banking system and argue that it was based on his view that free banking would result in the almost total suppression of the issue of new fiduciary media and thus produce a money supply that functioned exactly as a «purely metallic currency» (in the terminology of the currency school). Thus the reason for Mises's preference for a free banking 
system contrasts sharply with the view of modern free bankers, who predict that the regime of free banking would lead to continual expansion of fiduciary media to the point where gold would be completely expelled from circulation among the public, remaining in the monetary system as merely an interbank clearing asset (White and Selgin 1989). With the dawning of this «mature» stage of free banking the supply of money would therefore be essentially identical to the supply of bank notes and deposits, which the banking system would then continually and automatically adjust so as to prevent departures from monetary equilibrium induced by "money demand shocks.»

In arguing that Mises was a proponent of both the currency principle and free banking and that he viewed the latter as the indispensable means to achieve governance of the money supply by the former, I seek to reframe the debate on Mises's monetary views in a more meaningful way. My hope is that such a reframing will enhance mutual understanding between Austrians of the neocurrency school and those who sympathize with the modern free banking movement. ${ }^{2}$

The paper is divided into eight sections. The next section introduces the British currency school and describes the currency principle. Section 3 deals with the modern free banking school, describing the monetary equilibrium principle which it upholds as the norm for optimal monetary policy. Throughout his career Mises held the analytical achievements of the currency schoolin high esteemwhile recognizing and correcting the two crucial errors that vitiated the implementation of its policy in Great Britain in the mid-nineteenth century. This claim is documented in section 4. In section 5, Mises's defense of free banking is closely scrutinized, and it is demonstrated that Mises advocated free banking as the most effective means of eliminating the issue of fiduciary media and implementing the currency principle as the regulator of the money supply. Section 6 is devoted to Mises's analysis of the market mechanisms that would suppress credit

2 This does not imply that all free bankers are Austrians. For example, Lawrence H. White does consider himself an Austrian, while George Selgin rejects the designation as a description of his own views. 
expansion and fractional reserve banking under a regime of free banking. Mises's strong opposition to the issue of bank notes -whether fully backed by cash reserves or not- which has been completely ignored in the literature is noted in section 7 . Some concluding thoughts are presented in section 8 .

II

\section{SOUND MONEY AND THE CURRENCY PRINCIPLE}

Ludwig von Mises is generally considered the foremost proponent of «sound money» in the twentieth century. ${ }^{3}$ Mises, however, did not develop this principle himself, although he undoubtedly perfected it. He learned about sound moneyfrom a group of British bankers, merchants, and economists who wrote during the mid-nineteenth century. This group came to be famously known as the "currency school.» Its most prominent members were Robert Torrens, George Norman (Lord Overstone), and William Lloyd. 4

According to theprinciple of sound money developed by the currency school - which was then called the "currency principle»— a nation's money supply, defined to include gold coin and bullion plus bank notes immediately redeemable in gold, should be made to behave precisely as a «purely metallic currency.» In practice, this meant: first, that changes in the supply of bank notes must be rigidly linkedwith changes in the supply of gold; and second, that, therefore additional bank notes could

\footnotetext{
${ }^{3}$ Mises's emphatic and unwavering support for the classical gold standard even led Joseph Schumpeter (1968, p. 288, n. 3), an otherwise perceptive doctrinal scholar, to mistake Mises's "practical metallism» for «theoretical metallism,» although Schumpeter $(1968$, p. 289) himself points out that the two positions «need not go together.» In fact, Mises (1980, pp. 518-524) explicitly rejected «theoretical metallism.» See also the tribute to Mises as the foremost twentieth-century advocate of the gold standard by the Ordo-liberal economist Wilhelm Röpke (1969).

${ }^{4}$ For a detailed treatment of the historical background and doctrine of the currency school and of its famous controversy with the rival British «banking school,» see: Fetter 1978, pp. 165-97; Viner pp. 218-89; Wu 129-41; Daugherty 1942 and 1943; and Rothbard 1995, pp. 225-74 and the extensive literature on the topic that he cites in his bibliographical essay (pp. 489-91).
} 
be issued only in exchange for deposits of gold of equal denomination. Thus, under an international gold standard, variations in an individual nation's money supply would be determined strictly bythe net inflow or outflow of gold through the balance of payments or, if the nation possessed gold mines, also by production of new gold. Issue of additional «fiduciary media," i.e., notes and deposits unbacked by gold, thus would be totally suppressed.Consequently, prices would move in lockstep with world prices, and cyclical fluctuations in prices and output and the accompanying balance of payments crises would be abolished. Secular variations in the purchasing power of money would, of course, still occur but would depend solely on market forces affecting global gold supply and demand.

While the currency principle may seem like an alien doctrine in today's world, it is actually the principle that governs changes in the money supplies of different regions that use the same currency, such as the individual states composing the United States. Assuming that the overall supply of dollars is fixed,the supply of dollars in California, for example, would increase if the residents of the state become more productive and prosperous and demand more dollars by increasing their net exports of products to the rest of the country in exchange for dollars. California's money supply may also change if another state, say Michigan, suffers a decline in its industry and income and requires fewer dollars to finance its reduced transactions. In this case Michigan residents would exchange their redundant dollars for more imported products from California and the other states. Michigan's money supply would therefore decline and California's increase. Thus, where institutional arrangements permit the currency principle to operate, it ensures that market forces alone determine the overall quantity and value of money as well as the distribution of the money supply among different nations, states, regions, towns and even families participating in the market economy. ${ }^{5}$

${ }^{5}$ Even if the Fed were concurrently increasing the money supply, this interregional distribution process driven by demand side forces would continue to operate, although 
In addition, when variations in the money supply of a region or country that is part of a larger currency area is determined exclusively according to the currency principle, the change in the money supply is automatic and exactly equal to the inflow or outflow of money through the balance of payments. For example if Michigan experiences a balance of payments deficit of $\$ 1$ billion there is no need for its banks to increase the interest rate and contract the money supply by a multiple of this amount, because the money outflow reflects a decrease in market demand for money and is strictly self-limiting. It is not caused by a bank-induced expansion of the money supply accompanying a deliberate cheap money policy, so there is no tendency for an artificial boom followed by a gold outflow and deflationary depression, as there is when fixed exchange rates exist between fractionally backed currencies issued by independent national central banks. Rather the causation is the other way: the contraction in Michigan's money supply is the natural response to a fall in output and income that results from lagging productivity or a shift in U.S. demand away from Michigan's products.

Likewise, the influx of $\$ 1$ billion dollars into a prospering state like California does not necessitate a decline in interest rates and an induced expansion of the state's money supply beyond the amount of the original balance ofpayments surplus. That is, there is no «imported inflation» that creates an unsustainable boom followed by a bust in California. People have become relatively wealthier in California and demand to hold more cash to make additional transactions. Just as the market adjusts prices and incomes to reflect the new pattern of supplies and demands, italso, as part of the same process, redistributes the supply of dollars from Michigan to California-or more accurately, transfers dollar notes and bank deposits, one for one, from specific households in Michigan whose incomes and purchases are shrinking to those in California whose incomes and purchases are expanding. Moreover, assuming that intertemporal consumption preferences

its effect would be diluted to a lesser or greater extent by the injections of new dollars into the economy via open market operations. 
have not changed in either state, there is no reason to assume that inverse changes in interest rates (up in Michigan, down in California) must accompany the movement of money from one state to the other. ${ }^{6}$

Members of the currency school thus believed that an international gold standardundisturbed by the issue of fiduciary mediawould operate in much the same way as a homogeneous domestic currency. They formulated the currency principle, which would force the actual mixed currency of gold and convertible bank notes to behave as a pure metallic currency,as a means of abolishing the political and banking influence on the supply, value, and distribution of money.

By the time Misespublished his treatise on The Theory of Money and Creditin 1912, the currency school and its doctrines had long been discredited and were almost completely ignored by his fellow monetary economists. ${ }^{7}$ One of Mises's primary aims in this treatise and in his later writings on money was to revive the currency principle and seek to demonstrate its truth and practical application by giving it a firm foundation in modern monetary theory. Mises also developed the currency school's seminal theory of boom and bust into what came to be famously known as the "Austrian theory of the business cycle.» In an important sense, Mises was the founder of theneo-currency school, which includes manycontemporary Austrians. ${ }^{8}$

${ }^{6}$ For a detailed analysis of the differences between the balance-of-payments adjustment process operating under an internationally homogeneous, «pure» commodity currency and that operating under «mixed currencies» organized along national lines and including notes and deposits issued by fractional-reserve banks, see Hayek 2008, pp. 337-66. Hayek was especially emphatic in pointing out that movements of interest rates and «secondary» bank-induced inflation and deflation of the money supply were not characteristics of the balance of payments adjustment mechanism under a homogeneous international currency.

7 As Hülsmann (2007, p. 207) points out, the English translation of the title is significantly misleading; a more correct translation of the title of the German edition is The Theory of Money and Fiduciary Media.

8 On the neo-currency school, see Salerno 2010, pp. 497-533. 
III

THE FREE BANKING SCHOOL AND THE MONETARY EQUILIBRIUM PRINCIPLE

According to principle of monetary equilibrium, the supply of money must be continually expanded and contracted by the banking system in order to accommodate any changes in the demand to hold money. ${ }^{9}$ Following New Keynesian and other modern macroeconomists, modern free bankers use the term «aggregate demand shock» to characterize a situation in which people voluntarily choose to increase or decrease their holding of cash by spending less or more of their income on goods and services. ${ }^{10}$ Let me focus on the case in which individuals demand to hold more cash and therefore reduce their overall demand for goods and services below what it was in the previous time period. In this case, «monetary equilibrium» would be disturbed and the demand for money would suddenly exceed the supply of money. If nothing else changed, total spending would fall and there would be a corresponding decline in the scale of prices and incomes. As a result, the value of money would tend to rise but, since prices are not perfectly flexible and are subject to «nominal rigidities,» the appreciation would occur slowly and excess demand for money would persist. ${ }^{11}$ According to the free bankers, this protractedincrease in

9 The «monetary equilibrium principle» is a policy norm derived from the monetary disequilibrium theory of macroeconomic fluctuations. Of modern proponents of the theory, Leland Yeager is the most prominent. See Yeager 1997 for his seminal contributions to the theory. Selgin 1988 and Horwitz 2000 attempt to weave parts of the theory into a theoretical foundation for free-banking policy conclusions. For a comprehensive recent exposition of monetary disequilibrium theory, see Rabin 2004.

${ }_{10}$ See for example Selgin 1997, pp. 35-40.

11 This description of the monetary adjustment process will not be contested here. Suffice it to say that it is based on the New Keynesian theory of nominal price rigidities. This Keynesian approach ignores the step-by-step monetary adjustment process articulated by Mises (1998, pp. 337-43a) and Hayek (2008, pp. 351-359). In the Mises-Hayek analysis the protracted adjustment of the value of money to a change of its demand or supply has nothing to do with price rigidities (although it does not assume that prices are perfectly flexible) and is not marked by persistent shortages or surpluses of money. Rather it is a result of the fact that a change of the demand for money does not affect all goods' markets at once. For a detailed analysis of the Mises-Hayek monetary adjustment process that focuses on its methodological suppositions and constructs see Salerno 2010 (pp. 93-103); also see Davidson 2012. 
the value of money would be calamitous, causing unemployment and recession. Thus they advocate that any «excess demand» for money be offset by an equal increase in the supply of money. This would preserve monetary equilibrium, maintain the aggregate flow of spending constant, and prevent the purchasing power of money from increasing.

In modern macroeconomic jargon, the monetary equilibrium principle is nothing but a «nominal income target," although free bankers prefer that the target be achieved by a competitive banking system rather than Fed policy. However, until a free banking regime is implemented, free bankers propose that the Fed target a constant nominal incomeunder the rubric of the "productivity norm.» ${ }^{12}$ It is not surprising, then, that most modern free bankers, including Larry White and George Selgin, favored one or both of the Fed's «quantitative easing» programs. ${ }^{13}$ They believed that these unconventional expansionary monetary policies were necessary to offset the fall in consumption and investment expenditures caused by people's demand for greater cash balances to deal with the heightened uncertainty and risks associated with the financial crisis.

The free banking school, as its name implies, prefers an institutional arrangement in which a central bank does not exist, and

12 According to Selgin (1997 p. 34), «Formally, the argument here is essentially the same one found in many recent proposals and assessments of nominal income (GNP or GDP) targeting.» Nominal income targeting was first proposed in the 1970s by orthodox Keynesian monetary economist Benjamin Friedman $(1975 ; 1977)$. It later piqued the interest of New Classical and New Keynesian economists. See, for example, Hall and Mankiw 1994.

13 On free bankers endorsing the Fed's quantitative easing programs, see Bagus 2011; Harrison 2011; and Clougherty 2011. None of the free bankers who advocates a nominal income target for the Fed hasseriously addressed the question of precisely how «monetary equilibrium» produced spontaneously by a competitive banking industry could be achieved as a policy objective in the institutional context of a central banking regime. While sympathetic to free banking, Butos (2012) is extremely dubious that the competitive outcome of a free banking system can be legitimately translated into a policy norm for a monopolistic central bank to follow, because the latter operates under radically different institutional conditions from those framing a competitive banking system. In particular, the specific knowledge, incentives, and access to economic calculation that powerfully shape the behavior of free banks are for the most part unavailable to central monetary planners. 
unregulatedprivate fractional-reserve banks compete with one another in issuing bank notes and deposits convertible into gold (or silver). In the free bankers' view, a financial system of this kind would automatically ensure that the money supply always variesin a way that neutralizes money demand shocks and preserves monetary equilibrium. Competitive fractional-reserve banks would accomplish this by issuing just the right amount of newnotes and checking deposits to fully satisfy the increased demand for money. Since these additional notes and deposits would be unbacked by gold, the monetary equilibrium principle, in sharp contrast to the currency principle, implies that the issuing of fiduciary media is not only economically benign but critically necessary to the proper functioning of a market economy. Thus, by characterizing Mises as a monetary equilibrium theorist, the free bankers attribute this position to him also. ${ }^{14}$

IV

\section{MISES AND THE CURRENCY SCHOOL}

Throughout his writings, Mises recognized and lauded the lasting contributions of the currency school to monetary and business cycle theory and policy. In his first complete presentation of the Austrian theory of the business cycle, published in 1928, Mises (2006, p. 101, 128) stated:

Of all the theories of the trade cycle, only one has achieved and retained the rank of a fully-developed economic doctrine. That is the theory advanced by the Currency School, the theory which traces the cause of changes in business conditions to the phenomenon of circulation credit [that is, the issue of fiduciary

14 At the outset of the modern free banking movement, some free bankers maintained that Mises either rejected the monetary equilibrium doctrine altogether (Selgin 1988, pp. 61-62) or had an «ambiguous relationship» with it (Horwitz 2000, pp. 7778). Others, most notably Larry White (1992, p. 522), argued that Mises viewed the issuance of fiduciary media as «a natural and desirable development in a free society.» Partly in response to the present author (2010b and 2010c), both Horwitz (2010a and 2010b) and Selgin (2010) later abandoned their earlier views and more or less defended White's interpretation of Mises as a monetary equilibrium theorist. 
media $]^{15} \ldots$ Every advance toward explaining business fluctuations to date is due to the Currency School. We are also indebted to this School alone for the ideas responsible for policies aimed at eliminating business fluctuations.

In his earlier treatise, The Theory of Money and Credit, Mises credited thecurrency school as the main inspiration for the development of modern business cycle theory. There Mises (1980, pp. 282-83) commented that the currency school «propounded a theory, complete in itself, of the value of money and the influence of the granting of credit on the prices of commodities and the rate of interest.» While noting that the school's doctrines were based on the erroneous value theory of the classical school and a mechanical version of the quantity theory, Mises yet maintained, «Within its own sphere of investigation,» the currency school «was extremely successful.» «This fact,» he observed, «deserves grateful recognition from those who, coming after it, build upon the foundations it laid.»

Mises, however, did not allow his admiration for the currency school to blind him to the two key errors it committed. In fact he was eager to expose and correct these errors because they were the reason that the currency principle failed on the policy level when it was implemented in Great Britain bythe Bank Act of 1844 , more popularly known as Peel's Act. ${ }^{16}$ The first error was an analytical one. Unlike the opposing and inflationist banking school, the currency school failed to recognize that bank deposits were perfectly interchangeable with bank notes in exchange and, as such, were part of the money supply. Consequently, thecurrency principle's rigid restriction on the creation of fiduciary media was tragically weakened because Peel's Act

15 Mises (1980, pp. 296-300) distinguished between «circulation credit,» which is produced by bank credit expansion, and «commodity credit,» which involves the bank purely as an intermediary facilitating the transfer of credit from savers to investors. Fritz Machlup (pp. 224, fn. 4, 231-32) used the terms «created credit» and «transfer credit» respectively to more clearly denote these two different types of credit.

${ }^{16}$ For a discussion of Peel's Act and its aftermath, see Fetter 1978 (pp. 194-224) and Rothbard 1995 (pp. 248-66). 
applied only to bank notes, whilebankswere left free to create new, unbacked demand deposits ad libitum.

The second, practical flaw in the program of the currency school was its insistence that power to enforce the currency principle be centralized in a bank with monopolistic legal privileges-in this case the Bank of England. This quasi-central bank, in which most of the system's gold reserves were held, would then have the means and the power to enforce the currency principle for the banking system as a whole. In effect, the authors of Peel's Act unwittingly created the template for the modern inflationary and crisis-prone monetary and financial system. In the modern system, a central banksuch as the Fed is legally empowered to issue its own fiat notes and deposits which serve as the reserves for the commercial banks. The commercial banks, in turn, are permitted to create fiduciary media by pyramiding their own bank depositson these Fed liabilities.

The economic effects of Peel's Act were predictable: the British economy experienced recurring episodes of inflation which culminated in the crises and depressions of 1847, 1857, 1866, and 1890. During each of these crises, Peel's Act was suspended. Before the end of the nineteenth century, the currency principle and the entire currency school program had fallen into disrepute. Of course with each «emergency» suspension of Peel's Act by the British government, moral hazard became more pervasive and deeply ingrained in the British financial system, making future crises and suspensions even more likely.

Mises, nevertheless, believed that the currency principle embodied a seminal truth about the prevention of cyclical fluctuations and argued that its fatal neglect of bank deposits was easily corrected. Thus Mises (1980, pp. 407-408) brushed aside the critics of the currency school who sought to discredit its core doctrine by referring to its confusion over the nature of bank deposits:

[T] he doctrine of the Currency School does not stand or fall by its views on the nature of checks and deposits. It is enough to correct it on this one point - to take its propositions concerning the issue of notes and apply them also to the opening of deposit 
accounts - to silence the censures of those who adhere to the banking principle.

When Mises wrote the foregoing words in the second edition of his Theory of Money and Credit in 1924, he still had reservations concerning the currency school's aim of eliminating all further issue of fiduciary media. Mises (1980, p. 408) referred to thisgoal asa «heroic remedy with a vengeance» and pointed out that it would mean «renouncing all attendant advantages» of stabilizing the purchasing power of money.And yet, he wound up strongly affirming the currency principle at the very end of the book. Mises (1980, p. 447) did so in a long passage that he quoted from the first (German) edition of his book:

[I]t is obvious that the only way of eliminating human [i.e., politicaland banking] influence on the credit system is to suppress all further issue of fiduciary media. The basic conception of Peel's Act ought to be restated and more completely implemented... by including the issue of credit in the form of bank balances within the legislative prohibition.

Mises (1980, p. 448) continued, «It would be a mistake to assume that the modern organization of exchange is bound to continue to exist. It carries within itself the germ of its own destruction; the development of the fiduciary medium must necessarily lead to its breakdown.»17 (Emphases added.)

By 1928, however, there was no longer ambivalence: Mises had become a hard-line proponent of the currency principle. Near the end of his 1928 monograph on business cycle policy Mises (2006,

17 Compare Mises's currency school view of fiduciary media with the conditions White and Selgin envision under a «mature free-banking system» in which fiduciary media might completely displace the money commodity not only from circulation but from all monetary use. According to White and Selgin (1989, p. 235): «[A]t the limit, if inter-clearing-house settlements were made entirely with other assets [than gold]... and if the public were completely weaned from holding commodity money, the active demand for the old-fashioned money commodity would be wholly nonmonetary.» Of course, in such a scenario it would be absurd to speak of fiduciary media at all; all bank note and deposit «liabilities» would be privately issued fiat money. 
p. 150) proposed a revised currency school program to abolish cyclical fluctuations:

The most important prerequisite of any cyclical policy, no matter how modest its goal may be, is to renounce every attempt to reduce the interest rate, by means of banking policy, below the rate which develops on the market. That means a return to the theory of the Currency School, which sought to suppress all future expansion of circulation credit and thus all further creation of fiduciary media. However, this does not mean a return to the old Currency School program, the application of which was limited to banknotes. Rather it means the introduction of a new program based on the old Currency School theory, but expanded in the light of the present state of knowledge to include fiduciary media issued in the form of bank deposits.

The banks would be obliged at all times to maintain metallic backing for all notes - except for the sum of those outstanding which are not now covered by metal- equal to the total sum of the notes issued and bank deposits opened. That would mean a complete reorganization of central bank legislation. The banks of issue would have to return to the principles of Peel's Bank Act, but with the provisions expanded to cover also bank balances subject to check... By this act alone, cyclical policy would be directed in earnesttoward the elimination of crises.

And Mises (2006, p. 150) intended this policy to be applied not only to central banks but also to commercial banks that issued demand deposits. Thus he asserted: «In those countries where checking accounts at private commercial banks play an important role in trade - notably the United States and Englandthe same obligation must be exacted from those banks also.»

The evidence is clear, then, that even before the Great Depression, Mises championed the cause of the currency school and viewed the suppression of the issue of fiduciary media as the main prerequisite for the abolition of cyclical fluctuations. But if this is indeed the case, then how is it that Mises could advocate free banking, an institutional arrangement that legally permits the creation of fiduciary media by competitive private banks completely unregulated by legislation or a monopoly central bank? 


\section{$\mathrm{V}$ \\ FREE BANKING: TOWARD THE ELIMINATION OF FIDUCIARY MEDIA}

As I noted above, modern free bankers point to Mises's defense of free banking as strong evidence that Mises favored the issue of fiduciary media as a means of adaptingthe money supply to continual fluctuations in the demand for money. This monetary equilibrium principle was advocated, in much cruder form, by the British banking school, whose membersopposed the currency principle that changes in the money supply should be rigidly governed by changes in the supply of gold. ${ }^{18}$ Mises (1980, p. 406) explicitly rejected the banking principle, which he described as «the contrivance of an adjustment between the stock of money and the demand for money.»

Mises first discussed free banking in the final chapter of the Theory of Money and Credit, which dealt with the problems of credit. Mises began the chapter by noting that, since the time of the currency school, governments in Europe and the United Stateshad recognized the need to restrictbanks in their issue of fiduciary media in order to avoid economic crises. Following Great Britain, these governments adopted various legislative policies to restrict the issue of unbacked bank notes. After surveying these policies, Mises (1980, p. 410) concluded: «None of these many systems of limiting the note circulation has proved [sic] ultimately capable of interposing an insurmountable obstacle in the way of further creation of fiduciary media.» Mises (1980, p. 411) then pointed out that the only effective limit to the issue of fiduciary media was the failure of central banks to cooperate or collude in expanding credit: «So long as the banks do not come to an agreement among themselves, concerning the extension of credit,

18 The banking school appealed to the inane «principle of reflux» as the mechanism maintaining continuous equality between money supply and money demand. For a description and critique of the principle, see: Viner 1937, pp. 234-38; Wu 2007, pp. 135-138; and Rothbard 1995, p. 244. While modern free bankers reject the principle of reflux, they argue that, under free banking, the "adverse clearing mechanism," which will be discussed below, would prevent persistent departures from monetary equilibrium. 
the circulation of fiduciary media can indeed be increased slowly, but it cannot be increased in a sweeping fashion.» ${ }^{19}$ It was on this insight that Mises built his case for free banking as the most effective method of eliminating the further issue of fiduciary media.

Although he did not go on to make a sustained argument for free banking in The Theory of Money and Credit, Mises (1980, p. 435) did suggest that that the experience of government regulation of banking «has been incomparably more unfavorable than experience of uncontrolled private enterprise.» More important for my purposes here, Mises had formulated the problem that is to be solved by free banking as one of suppressing further creation of unbacked bank notes and deposits.

Mises discussed the topic of free banking in a little more detail in 1928 in his monograph on business cycle policy. There he made three key points regarding thelimitation on the expansion of fiduciary media under free banking. To begin with, individual banks would learn to exercise extreme caution in issuingfiduciary media because no legal tender laws would exist to force their acceptance among the public. The public, on their part,eventually would learn the difference between trustworthy and inferior brands of notes and deposits. Thus, if a bank engaged in imprudent and recklesscredit expansion, itsbrand of notes and deposits would suffer a loss of reputation and ejection from circulation. They would no longer qualify as money substitutes that are generally acceptable at face value in exchange. In the course of time,according to Mises (2006, p. 124), «solvent and highly respected banks would emerge... whose fiduciary media would enjoy the general confidence essential for money-substitute quality.» This would be the case because themanagers of these banks «would have learned from past experiences.»

This brings us to his second point. Mises (2006, p. 125) contended that once a solid core of banking institutions had gained widespread trust and become well-established, the less responsible banks would be compelled to «follow suit» and become more

${ }^{19}$ Outside the Anglo-American countries, central banks were the main issuers of fiduciary media at the time that Mises wrote this. 
prudent in issuing and lending their own brands of fiduciary media. Any bank that issued it notes and deposits in relative excess compared to the most conservative institutions would soon find itself with a negative balance on interbank clearings. That is, the volume of its own notes presented to it for payment by other banks would exceed in nominal value the volume of notes issued by other banks that it had accumulated and was presenting for exchange. It would have to make up its deficit on note clearing by paying in gold and this would result in a loss of cash reserves and a deteriorating reputation. If the irresponsible bank did not promptlyrestrict its emission of fiduciary media, losses of reserves would become chronic and provokea loss of confidence and a bank run by its own depositors and noteholders.

Mises concluded his discussion by making his third, and most important, point: the overall evolution of the free banking system tended toward the ideal of the currency school. Wrote Mises (2006, p. 125):

In the course of the development of a banking system with fiduciary media, crises could not have been avoided. However, as soon as bankers recognized the dangers of expanding circulation credit, they would have done their utmost, in their own interests, to avoid the crisis. They would then have taken the only course leading to their goal: the extreme restraint in the issue of fiduciary media.

\section{VI \\ LIMITS ON FIDUCIARY MEDIA: ADVERSE CLEARING VERSUS BRAND EXTINCTION}

It was not until Human Action, first published in 1949, however that Mises fully spelled out the market mechanisms by which free banking would come to impose rigid limits on the emission of fiduciary media. Significantly, Mises (1998, pp. 431-445) discussed free banking in the section entitled: "The Limitation of the Issuance of Fiduciary Media.» Throughout this section, Misesemphatically reiterated his view that free banking is the most 
effective monetary arrangement for stifling the creation of fiduciary media. For example, Mises wrote (1998, p. 439): «The establishment of free banking was never seriously considered precisely because it would have been too efficient in restricting credit expansion.» Mises (1998, p. 439, fn. 17) then continued in a footnote to this passage:

The notion of «normal» credit expansion is absurd. Issuance of additional fiduciary media, no matter what its quantity may be, always sets in motion those changes in the price structure the description of which is the task of the theory of the trade cycle.

In another passage, Mises (1998, p. 440) argued:

Free banking is the only method available for the prevention of the dangers inherent in credit expansion. It would .... not hinder a slow credit expansion, kept within very narrow limits, on the part of cautious banks which provide the public with all information required about their financial status. But under free banking it would have been impossible for credit expansion with all its inevitable consequences to have developed into a regular... feature of the economic system. Only free banking would have rendered the market economy secure against crises and depressions.

I quote one last statement from Mises (1998, pp. 437-38):

If the governments had never interfered for the benefit of special banks, if they had never released some banks from the obligation, incumbent upon all individuals and firms in the market economy, to settle their liabilities in full compliance with the terms of the contract, no bank problem would have come into being. The limits which are drawn to credit expansion would have worked effectively. Considerations of its own solvency would have forced every bank to cautious restraint in issuing fiduciary media. Those banks which would not have observed these indispensable rules would have gone bankrupt, and the public, warned through damage, would have become doubly suspicious and reserved.

Any reasonable interpretation of the foregoing passages and their context suggests that Mises held firmly to two positions. 
First, the creation of fiduciary media in any amount precipitatesa cyclical boom and bust. Second, free banking is an effective remedy for business cycles precisely because its operation would result in rigid limitation, if not complete suppression, of bank credit expansion. ${ }^{20}$

But what was the origin and nature of thelimits on credit expansion that Mises referred to in his writings on free banking? Mises's answer to this question was that the forces restricting the creation of fiduciary media are inherent in the very concept of a «money substitute.» Mises (1998, p. 429) defined money substitutes as «claims to definite sums of money, against a debtor about whose solvency and willingness to pay there does not prevail the slightest doubt.» Besides «undoubted solvency and willingness to pay on the part of the debtor,» these claims need to embody the additional quality of «daily maturity» in order to qualify as a money substitute. That is, the issuer must be ready and willing to redeem the claim for money on demand and without charge to the holder. Finally, even if a claim embodied both these qualities, it would render the same services as money to an individual only if all the parties that he exchanged with were «perfectly familiar» with the qualities of the claim.

Historically most money substitutes have taken the form of bank notes and demand deposits, which may or may not have been fully backed by actual money. Mises was only concerned with limiting the issue of fiduciary media, that is, the fraction of money substitutes that isunbacked by cash or «money proper.» ${ }^{21}$ For it is only the issue of unbacked bank notes and deposits that

20 In fact, in an early work, Selgin (1988, p. 62) seemed to attribute precisely this second position to Mises when he wrote: «Indeed, Mises's support for free banking is based in part on his agreement with Cernuschi, who... believed that freedom of note issue would automatically lead to 100 percent banking.» Cernuschi was a nineteenth-century French economist who, as we shall see below, was favorably cited by Mises.

21 Mises (1998, pp. 429-31) distinguished between «money proper» and «money in the broader sense.» The supply of money proper referred to cash, e.g., gold coin and bullion under the gold standard or Fed-issued currency notes and reserve deposits under the current fiat-dollar standard. The supply of money in the broader sense comprised money proper plus that fraction of money substitutes unbacked by cash, i.e. fiduciary media in the form of commercial bank notes and deposits. In current 
expand the money supply, diminish the purchasing power of money, and artificially reduce theloan rate of interest below the natural rate determined by the market. The emissionof notes and deposits fully backed by money proper, which are called «money certificates, $\gg$ have no effect on market phenomena. They merely replace the actual gold in circulation with a title to an equal amount of gold now stashed in bank vaults, leaving the money supply unchanged.

In analyzing the potential limits on the creation of fiduciary media, Mises (1998, pp. 432-36) presentedtwo scenarios. In the first scenario, there is a single bank whose clientele includes all households and firms either in the entire world or in a single isolated country. Even in this case there is a broad limit that is imposed by the necessity of maintaining the public's confidence in the bank, because a loss of confidence would precipitate mass redemption of bank notes and deposit withdrawals. The bank thus must avoid any action that arouses suspicion among the public. How far it can extend its issue of fiduciary media and expand the money supply, especially if its clients start to expect price inflation to accelerate, depends on unpredictable psychological conditions.

In Mises's second scenario there co-exists a «multiplicity of independent banks,» but the banksdo not collude in expanding credit. It is further assumed for simplicity that no firm or household is a client of more than one bank. Now suppose that one bank alone creates additional fiduciary media, while all other banks refrain from expansion. The borrowers who receive the loans from this bank are now in a position to bid for additional goods and services on the market. This increase in demand causes prices to rise and goods to be redistributed to the clients of the expanding bank, forcing clients of all other banks to cut back on their purchases. As a result, a balance of payments deficit develops for the clients of the expanding bank as they now must make greater aggregate payments to non-clients than they receive from

jargon these two monetary aggregates are roughly equivalent to base money and M1, respectively. However, Mises's crucial emphasis on bank notes and deposits as money substitutes is missing in the modern literature. 
them. However, the deficit cannot be paid for with the newly issued money substitutes from the expanding bank because they are not recognized and treated as such by the non-clients. That is, the notes and deposits of the expanding banksdo not function as money substitutesin these transactions. Payments to non-clients thusmust take the form of actual money. Consequently, the expanding bank is forced to redeem its bank notes and checkable deposits in cash for its clients, which causes its gold reserves to diminish. The bank must eventually cease its credit expansion or run the risk that its reserves will plummet tozero, at which point it would be unable to redeem the remainder of its money substitutes outstanding and become insolvent.

Modern free bankers stress this "principle of adverse clearing» as the primary, if not the only, mechanism by which the issue of fiduciary media by an individual free bankis limited (Selgin, 1988, pp. 40-47; White 2010). For Mises, however, long before the reserves of the relatively expansionary bank have been exhausted by the adverse balance of payments faced by its clients, another factor would operate to extinguish the character of its notes and deposits as money substitutes. This factor is a loss of confidence on the part of its ownclients in the bank's ability to discharge its debts in a timely manner. This loss of «good will» would cause its clientele to shrink rapidly. This means that fewer and fewer people would be willing to accept and hold the bank's notes and deposits as money substitutes. Even if everyone were still willing to accept the discredited notes in loans and payments rather than forego the loan or sale, they would all rush to spend them as soon as possible rather than hold them in their cash balances. The notes would thus begin to trade at a discount and those who accepted these discounted notes would earn an arbitrage profit by returning them to the issuing bank for payment at full face value in cash. At this point a bank run would become inevitable. ${ }^{22}$ But, for Mises, the

${ }^{22}$ In the earlier literature, the loss of gold reserves to a bank's clients was called an «internal drain,» and was distinguished from the «external drain» of gold reserves associated with the price-specie-flow or adverse clearing mechanism. See Viner 1937, pp. 161-64. 
note brand qua money substitute vanishes prior to the reserve drain and precipitates it. ${ }^{23}$

Mises believed that this latter mechanism, which derives from the inherently precarious position of money substitutes under free banking, would act swiftly and effectively to rigidly constrain the issue of fiduciary media among free banks. It is worth quoting Mises at length (1998, p. 436) describing what may be called the «mechanism of brand extinction»:

It is very easy for a bank to increase the number of people who are ready to accept loans granted by credit expansion and paid out in an amount of money-substitutes. But it is very difficult for any bank to enlarge its clientele, that is, the number of people who are ready to consider these claims as money-substitutes and to keep them as such in their cash-holdings. To enlarge this clientele is a troublesome and slow process, as is the acquisition of any type of goodwill. On the other hand the bank can lose its clientele very quickly... It was a serious blunder to believe that the reserve's task is to provide the means of for the redemption of those bank notes the holders of which have lost confidence in the bank. The confidence which a bank and the money-substitutes it has issued enjoy is indivisible. It is either present with all its clients or it vanishes entirely. If some of the clients lose confidence the rest of them lose it too. No bank issuing fiduciary media and granting circulation credit can fulfill the obligations which it has taken over in issuing money-substitutes if all clients are losing confidence and want to have their banknotes redeemed and their deposits paid back. This is an essential feature or weakness of the business of issuing fiduciary mediaand granting circulation credit. [Emphases added.]

Now, this does not mean that Mises ignored the adverse clearing mechanism; but he did assign it a secondary role as an

23 Although Mises never used the term «brand» in his discussion, a money substitute, as he construes it, can exist only as a branded entity. An unbranded money substitute, that is, one that does not identify a specific issuer, defies economic logic. In contrast, all other «products» on the market could conceivably perform their intended function in satisfying wants without being branded. Curiously, in his own treatment of discrimination between note brands, Selgin (1988, pp. 42-47) fails to cite Mises's path breaking contribution. 
economic feedback mechanism for a bank that exercised extreme restraint in issuing fiduciary media and had already established its note (and deposit) brand as a viable money substitute. ${ }^{24}$ For such banks an adverse clearing balance signaled an issue of notes in excess of what its clients wished to hold in their cash balances that required immediate redemption. But in the event of a «loss of confidence» in a particular brand of money substitute, the bank's reserves would be «futile» in securing «the prompt redemption of banknotes and the prompt payment of deposits» (Mises 1998, p. 436). In other words, Mises held that a high or low reserve ratio is not directly relevant to the stability of a bank. It is simply one of the objective data that the bank's clients take into account in formulating their subjective judgment concerning whether the banks notes and deposits are or are not money substitutes. These objective data also include past performance of the bank's loan and investment portfolio, its customer service, its physical facilities, the qualifications and experience of its managerial staff, its geographical accessibility, etc.

In short Mises argued that a fractional-reserve bank's «stability» consisted of a binary set of possibilities: either the bank's note brandis perceived as possessing all the qualities of a money substitute or the brand becomes extinct. Indeed, technically it is even inaccurate to speak of a brand becoming extinctor of a process of brand extinction, despite the fact that it takes more or less time for the bank's reserves to be exhausted. The brand is extinct the instantits clientele begins to distrust the bank's ability to fully discharge its note liabilities on demand. ${ }^{25}$ As Mises (1998, pp. 442, 444) emphasized

${ }^{24}$ For the rest of this discussion, I will use the term «bank» interchangeably with «issuers of money substitutes,» and the term «bank notes» to denote all of a bank's demand liabilities.

25 As Jeff Herbener (2002, p. 83) has perceptively noted, in Mises's view:

[P]eople only demand money-substitutes, not fiduciary media, and their demand exists only when they have confidence in full redemption based on the issuers' practice of full redemption. People could not demand fiduciary media because they cannot distinguish between a money-substitute that is a money-certificate and one that is a fiduciary medium. If they could make such a distinction, then fiduciary media would not be viable. 
What makes a banknote a money-substitute is the special kind of good will of the issuing bank. The slightest doubt concerning the bank's ability or willingness to redeem every banknote without any delay at any time and with no expense to the bearer impairs this special good will and removes the banknote's character as a money-substitute. ... One must not forget that every bank issuing fiduciary media is in a rather precarious position. Its most valuable asset is its reputation. It must go bankrupt as soon as doubts arise concerning its perfect trustworthiness and solvency.

It is important to note that in the foregoing passages Mises does not distinguish between the «illiquidity» and «insolvency» of a fractional reserve bank, as modern free bankers do. The quality of its loan and investment portfolio is an objective factor that does not directly affect the status of its demand liabilities as money substitutes. It is the «special good will» Mises speaks of that induces a bank's clients to forebear at every moment from immediately exercising their contractual right to redeem their notes for cash and that thereforepermits the issuer of money substitutes to continue in business. Thus good will, for Mises, is the solvent bank's «most valuable asset» that, in effect, bridges the inherent gapbetween, on the one hand, the sum of the bank's cash reserves plus the liquidation value of its loans and investmentsand, on the other, the value of its demand liabilities.

Mises's analysis of this point has an important, and heretofore unnoticed, implication for the appropriate accounting procedure for issuers of money substitutes. In order to reflect the reality of the special contractual obligation assumed by banks, all assets should be carried on their books at liquidation value. ${ }^{26}$ Thus for fractional-reserve banks there is no meaningful distinction between «illiquidity» and «insolvency.» 27

26 The market value of a bank's loans and investments is potentially extremely volatile and may fluctuate greatly with economic and financial conditions. However, at any given moment, good will is a binary variable: its value is either sufficient to maintain the bank's assets equal to the total nominal value of its demand liabilities or it is zero-meaning negative net worth and insolvency. There is never any intermediate state of «illiquidity» for a fractional reserve bank.

27 The liquidation value of cash reserves of course is always equal to their par value. This means that issuers of money substitutes that are fully backed by money 
Now it is important to emphasize that, unlike Murray N. Rothbard (2008, pp. 85-110) Mises was not arguing that fractionalreserve banks are inherently bankrupt. Mises's point was rather that a fractional-reserve bank is a uniquely and inherently unstable market institution, whose solvency depends on acquiring and maintaining a special intangible factor that is liable to vanish instantly. This special good will is a specific, non-isolable, and non-exchangeable factor required in the production function of every firm issuing money substitutes.

We might speculate briefly on why there is no discussion in the free banking literature of the brand extinction mechanism, or of anything akin to it, despite the fact that it plays such a prominent role in Mises's analysis of free banking. While this issue would require a separate paper to fully disentangle, I suggest that it lies in the fact that free bankers reject Mises's concept of money substitute in favor of the inside/outside money dichotomy. For example, White (1986, p. 314 n. 23) criticizes the term money substitutes as «confusing» because the term suggests «nonmoneyness.» However, by substituting the terms "outside money» to denote commodity or fiat money and «inside money» to denote notes and deposits issued by private banks, the free bankers obscure the fact that the "moneyness, , if one wishes to call it that, of inside money originates and vanishes according to distinctly different principles than those that apply to outside money. Specifically, the circulation of commodity money or fiat money is not dependent on the existence of specialgood will attaching to its producer; nor is outside money subject to the principle of brand extinction in the same sense as bank notes and deposits. ${ }^{28}$

As a side note, the adoption of the terms «inside money» and «outside money» by modern free bankers appears paradoxical. The concepts wereoriginally developed in 1960 by Gurley and

\footnotetext{
proper, i.e., 100 percent-reserve banks, need no «special good will» to maintain balance between assets and demand liabilities. They, of course, require general customer good will like any other ongoing firm that seeks to earn profits.

28 This is not to deny that the value of fiat money can be destroyed by hyperinflation or the dissolution of the issuing government by revolution or war; or even that the value of a commodity money like gold could conceivably approach zero if a technological advance were to radically alter its conditions of scarcity.
} 
Shaw (1960), whose aim was to challenge the real balance effect re-introduced into neoclassical monetary theory by Don Patinkin. A highly technical theoretical debate ensued which concluded without a completely satisfactory resolution. ${ }^{29}$ The inside/outside money conceptual apparatus quickly fell into disuse and by 1980 the monetary theorist Jürg Niehans (1980, p. 203, fn. 9) would declare: «The distinction between inside money and outside money is simply irrelevant. It is part of the analytical fallout from the confusion about real balance effects.»

The paradox of free bankers appropriating this defunct distinction lies in the fact that the real balance effect is at the very heart of the monetary equilibrium approach that they champion. ${ }^{30}$ But the use of the term in the free banking literature may not beso puzzling when it is considered that the eminent Keynesian monetary theorist James Tobin (1963, p. 410 fn. 2) cited Gurley and Shaw's work as important in "originating and contributing» to the «new view» of money of which Tobin was the leading proponent. In brief, according to the «new view,» private fractionalreserve banksarejust garden-variety financial intermediaries, like insurance companies or pension funds, and are not able to unilaterally create money at the stroke of a pen as almost all money and banking textbooks have taught for decades. ${ }^{31}$ And indeed, Selgin (1988, pp. 82-84) favorably cites Tobin's work as supporting his own argument that, absent a "monopoly bank of issue,» free banks are purely "credit transferers or intermediaries, and not credit creators.»

Our discussion is not intended as a criticism of the free bankers for embracing the distinction between inside and outside money.

29 This debate is recounted in Johnson (1967, pp. 75-85).

30 To be fair, Larry White (1999, p. 12 fn. 12) says that his use of the «distinction between inside and outside money is different from the one used by Gurley and Shaw.» Also, the distinction has been resurrected in more recent monetary literature although it is used for a different purpose, and inside money has a different definition than that originally assigned to it by Gurley and Shaw (Lagos 2006).

${ }^{31}$ Stated Tobin (1963, p. 418): «Commercial banks do not possess, either individually or collectively, a widow's cruse which guarantees that any expansion of assets will generate a corresponding expansion of liabilities... Marshall's scissors of supply and demand apply to the "output" of the banking industry, no less than to other financial and nonfinancial industries.» 
Rather the aim is to emphasize that the theoretical foundations of the distinction are rooted in a variant of monetary theory that is much closer to the banking school's view of the function of banks than it is to Mises's currency school perspective on banking.

\section{VII}

\section{A NOTE ON THE (BANK) NOTE}

One aspect of Mises's thought on free banking that has been completely overlooked is his highly skeptical view of the advantages of bank notes and his promotion of free banking as a method of totally suppressing their circulation. ${ }^{32}$ The reason for Mises's hostility to bank notes was that they were the main vehicle through which fiduciary media were issued. In continental Europe, checkable deposits were not generally subject to legal reserve requirements. Yet, their creation did not lead to multiple bank credit expansion, because almost all those who received payment by check cashed it immediately and did not redeposit the funds. ${ }^{33}$ According to Mises (1998, p. 442), "the public was not ready to treat such bank deposits as moneysubstitutes.» Only a small group of big firms treated checkable deposits at the central bank (but not commercial banks) as money substitutes. The opportunity for bank credit expansion via demand deposits was therefore nonexistent for commercial banks and very narrowly limited for central banks in continental

32 The sole exception that I have come across so far in the literature is Herbener 2002 (p. 86). In this pioneering article, Herbener presents an interpretation of Mises's views on money and banking policy that is close to the one presented here.

33 Explained Mises (1998, p. 443):

As far as payees immediately cash the checks received and withdraw the whole amount form the bank, the method [of paying employees by check] means merely that the onerous burden of manipulating coins and banknotes is shifted from the employers cashier to the bank's cashier. It has no catallactic implications. If all citizens were to deal in this way with check received, the deposits would not be money-substitutes and could not be used as instruments of credit circulation. 
Europe. ${ }^{34}$ As Mises (1998, p. 442) noted in 1949, with the exception of countries under the sway of Anglo-Saxon banking methods, «Banknotes were practically the sole instrument of credit circulation and credit expansion.» Things were otherwise in the U.S., where "a considerable part of the public looks upon deposits as money-substitutes [making] them what is popularly called checkbook currency.» Mises's opposition to bank notes thus stemmed from the fact that in most major countries up to the mid-20 ${ }^{\text {th }}$ century, bank notes were the primary form in which fiduciary media were created.

Indeed, in several statements Mises argued that one of the primary virtues of free banking was that its operation would suppress the issue of all bank notes, including those fully backed by gold. His argument was that the business of issuing money certificates was extremely expensive and risky and that a bank's clients may not be prepared to reimburse such high costs through fees paid for the marginal convenience of carrying notes and holding deposits instead of coins. Mises (1998, p. 432) therefore concluded that issuing money certificates, in order to be profitable, would almost inevitably have to be associated with the issuing of fiduciary media:

Issuing money-certificates is an expensive venture. The banknotes must be printed, the coins minted; a complicated accounting system for the deposits must be organized; the reserves must be kept in safety; then there is the risk of being cheated by counterfeit banknotes and checks. Against all these expenses stands only the slight chance that some of the banknotes issued may be destroyed and the still slighter chance that some depositors may forget their deposits. Issuing money-certificates is a ruinous business if not connected with issuing fiduciary media.

Furthermore, Mises (1998, pp. 443-44) argued, the widespread use of bank notes was invariably a product of government intervention and not of the private market:

${ }^{34}$ In terms of the money supply process taught in modern money and banking textbooks, the currency/deposit ratio was nearly infinite and the deposit multiplier was therefore practically zero. 
[F]reedom in the issuance of banknotes would have narrowed down the use of banknotes considerably if it had not entirely suppressed it... Governments did not foster the use of banknotes in order to avoid inconvenience to ladies shopping. Their idea was to lower the rate of interest and to open a source of cheap credit to their treasuries... If the governments had never interfered, the use of banknotes and of deposit currency would be limited to those strata of the population who know very well how to distinguish between solvent and insolvent banks. No large scale credit expansion would have been possible.

Mises (1998, p. 444) emphatically concluded:

Banknotes are not indispensable. All the economic achievements of capitalism would have been accomplished if they had never existed. Besides, deposit currency can do all the things banknotes do.

Once we recognize Mises's opposition to the bank noteper se, and not just as a form of fiduciary media, his approving quotation of the famous statement byFrench economist and free banker Henri Cernuschitakes on a different meaning than previously ascribed to it.Taken in its full context it is clear that Mises's point is that free banking would not merely restrict the emission of unbacked bank notes, but would result in wholesale brand extinction of nearly all bank notes. Declared Mises (1998, p. 443):

[F]reedom in the issuance of bank notes would have narrowed down the useof bank notes considerably if it had not entirely suppressed it. It was this idea that Cernuschi advanced in the hearings of the French Banking Inquiry on October 24, 1865: «I believe that what is called freedom of banking would result in a total suppression of banknotes in France. I want to give everybody the right to issue banknotes so that nobody should take any banknotes any longer.»

Mises's attitude toward the bank note as expressed in his analysis of free banking may partially explain a puzzling element in his proposal for post-World War Two monetary reform. Mises's reform program was published in 1953 as part of the section on 
«Monetary Reconstruction» that he added to the second edition of The Theory of Money and Credit (Mises 1980, pp. 451-500). The central recommendation in this program was for the United States to return to the classical gold standard at a fixed legal parity established at the market price for gold prevailing at the (pre-announced) date of initiation of the reform. He also recommended, in accordance with the currency school principle, thatall further issue of U.S. dollars, in any form, be subject to a strict 100 percent gold reserve requirement. This prohibition on issue of fiduciary media would not only apply to new dollar notes which would henceforth be issued by a Conversion Agency subject to a 100-percent gold reserve requirement. Mises (1980, 491) also explicitly applied it to the creation of deposits by commercial banks:

The total amount of dollar bills, whatever their name or legal characteristic may be, must not be increased by further issuance. No bank must be permitted to expand the total amount of its deposits subject to check or the balance of such deposits of any individual customer... otherwise than by receiving such cash deposits in legal-tender bank notes from the public or by receiving a check payable by another domestic bank subject to the same limitations. This means a rigid 100 percent reserve for all future deposits... ${ }^{35}$

Mises (1998, p. 494) was not satisfied with this general quantitative restriction on the issuance of bank notes, however. He went even further and prescribed that the Treasury be mandated «to withdraw from circulation, against the new gold coins, and to destroy within a period of one year after the promulgation of the new legal gold parity of the dollar, all notes of five, ten, and perhaps also twenty dollars.» Thus new legal tender notes «must

35 Note that Mises's program for postwar monetary reform resembles a currency board arrangement, but it went beyond it to legally require that not onlythe notes issued by the currency board be 100-percent backed by gold, but also that the demand deposits created by commercial banks be subject to the same legal mandate. For a discussion of the similarities and differences between Mises's plan and the modern currency board, see Salerno 2010a, pp. 484-94, 516-27. 
be issued in denominations of one or fifty dollars and upward.» In current dollars, this means that aside from the one-dollar bill, which would be tantamount to small change, there would be no note in circulation with a purchasing power of less than $\$ 450 !^{36}$ Now this further restriction on the minimum denomination of currency notes issued was never a part of the original currency school program. The reason that Mises insisted on itin his postwar monetary reform proposal was to ensure that people who had grown accustomed to using a paper money tenuously linked to gold since the advent of World War Onewere again familiarized with gold money. ${ }^{37}$ But it also reflected his strong conviction that bank notes were not indispensable to economic development and growth, and that the complete suppression of bank note issue would be the ideal outcome of a free banking regime.

\section{VIII CONCLUSION}

From the abundant and systematic evidence presented in this paper, I believe that it is reasonable to conclude that very early in his writings on monetary and business cycle theory, Mises arrived at two views from which he never deviated for the rest of his career. ${ }^{38}$ The first was that the creation of fiduciary media under any and all circumstances causes a divergence of the loan rate from the natural rate, leading to the sequence of phenomena described by Austrian business cycle theory. The second was that free banking is the best policy available for bringing about the goal of the currency school and Peel's Act: the eradication

36 This figure is calculated by comparing the purchasing power of the dollar between the years 1950 and 2010 using the inflation calculator available at http:// www.westegg.com/inflation/.

37 Thus Mises (1998, p. 493) wrote: «Gold must be in the cash holdings of everyone. Everybody must see gold coins changing hands, must be used to having gold coins in his pockets, to receiving gold coins when he cashes his paycheck, and to spending gold coins when he buys in a store.»

38 Indeed, as pointed out above (pp. 14-15, 17-8), the seeds of these views were clearly present in 1912 in the first German edition of The Theory of Money and Credit. 
of the issuance of fiduciary media. In short, Mises's overarching aim in his work on money and business cycleswas to revive, correct,and advance the currency school's theoretical approach and to formulate a practical program that would effectively achieve its policy goals.

If my interpretation is correct, then the ongoing debate over whether Mises was a «free banker» or an advocate of 100-percent reserves is exposed as superficial and ultimately irrelevant.The proper foci of the debate are the positions that Mises took on two critical theoretical propositions.The first is that any increase in fiduciary media generates a business cycle, implying a rejection of a key tenet of monetary equilibrium theory propounded by modern free bankers. The second is that under a system of free banking the behavior of the overall money supply tends to approximate its behavior under a 100-percent commodity money. This paper has provided overwhelming textual evidence that Mises strongly and persistently affirmed both propositions. As a result, it appears that the claim of modern free bankers that Mises was one of their theoretical forerunnersis highly implausible.

\section{BIBLIOGRAPHICAL REFERENCES}

BAGus, PH. (2011): «Who's Afraid of Deflation?» Mises Daily (July 22). Available at http://mises.org/daily/5465.

Butos, W. (2012): «Monetary Orders and Institutions: A Hayekian

Perspective.» The Quarterly Journal of Austrian Economics.

Forthcoming.

Clougherty, T. (2011): «Hayek and Monetary Stabilization.» The Cobden Centre (August 3). Available at http://www. cobdencentre.org/tag/lawrence-h-white/.

DAugherty, M.R. (1942): «The Currency-Banking Controversy,

Part 1.» Southern Economic Journal, 9 (October): 140-55.

- (1943): «The Currency-Banking Controversy, Part 2.» Southern Economic Journal, 9 (January): 241-50.

DAVIDSON, L. (2012): «Against Monetary Disequilibrium Theory and Fractional Reserve Free Banking.» The Quarterly 
Journal of Austrian Economics, Vol. 15, ․․ 2 (Summer): 195220.

Fetter, F.W. (1978): The Development of British Monetary Orthodoxy, 1797-1875. Fairfield, NJ: Augustus M. Kelley Publishers.

FRIEDMAN, B.M. (1975): «Targets, Instruments and Indicators of Monetary Policy.» Journal of Monetary Economics, I (October), pp. 443-473.

- (1977): «The Inefficiency of Short-Run Monetary Targets for Monetary Policy.» Brookings Papers on Economic Activity, N. ㅇ 2, pp. 293-335.

Gurley, J. G. and Shaw, E.S. (1960): Money in a Theory of Finance. Washington, D.C.: The Brookings Institution.

HALL, R.E. and MANKIW, N.G. (1994): «Nominal Income Targeting,» in Mankiw, ed. Monetary Policy. Chicago: The University of Chicago Press, pp. 71-94. Available at http:/ / www.nber. org/chapters/c8329.pdfhttp:/ / www.nber.org/chapters/ c8329.pdf.

HARRISON, E. (2011): «Lawrence White on Friedrich von Hayek.» Credit Writedowns (January 21). Available at http:/ / www. creditwritedowns.com/2011/01/lawrence-white-onfriedrich-von-hayek.html.

HayeK, F.A. (2008): Prices and Production and Other Works: F.A. Hayek on Money, the Business Cycle, and the Gold Standard. Ed. Joseph T. Salerno.Auburn, AL: Ludwig von Mises Institute.

Herbener, J.M. (2002): «Ludwig von Mises on the Gold Standard and Free Banking.» The Quarterly Journal of Austrian Economics, Vol. 5, ‥ 1 (Spring): 67-91.

Horwitz, S. (2000): Microfoundations and Macroeconomics: An Austrian Perspective. New York, NY: Routledge.

- (2010a): Comment on Peter Boettke, «Mises on Free BankingWhy Is There a Debate?» Coordination Problem Blog (May 7). Available at http://www.coordinationproblem.org/ 2010/05/mises-and-free-banking-why-is-there-a-debate. html.

- (2010b): Comment on Joseph T. Salerno, «Selgin contra Horwitz and White on Mises's View of Fiduciary Media.» Mises 
Economics Blog (May 16). Available at http:/ / archive.mises. org/12724/selgin-contra-horwitz-and-white-on-misessview-of-fiduciary-media/\#comment-688782.

Hülsmann, J.G. (2007): Mises: The Last Knight of Liberalism. Auburn, AL: Ludwig von Mises Institute.

Johnson, H.G. (1967): Essays in Monetary Economics. Cambridge, MA: Harvard University Press.

LAGOS, R. (2006): «Inside and Outside Money.» Federal Reserve Bank of Minneapolis Research Department Staff Report 374 (May).

Machlup, F. (19409: The Stock Market, Credit, and Capital Formation.

Trans. Vera C. Smith. London: William Hodge and Company, Limited

Mises, L. vON (1924): Theorie des Geldes und der Umlaufsmittel. $2^{\text {nd }}$ ed. Munich.

- (1980): The Theory of Money and Credit. $3^{\text {rd }}$ ed. Trans. H.E. Batson. Indianapolis: Liberty Classics.

- (1998): Human Action: A Treatise on Economics. Scholar's ed. Auburn, AL: Ludwig von Mises Institute.

- (2006): The Causes of the Economic Crisis and Other Essays before and after the Great Depression. Ed. Percy L. Greaves, Jr. Auburn, AL: Ludwig von Mises Institute.

MonTGOMERY, M.R. (2006): «The Genesis of an Idea: Classical Economics and the Birth of Monetary Disequilibrium Theory.» In Roger Koppl, ed., Money and Markets: Essays in Honor of Leland B. Yeager. New York: Routledge.

NAIR, M. (2012): «Regulation in a Nineteenth Century Indigenous Banking System as a Bankers' Club.» Working Paper.

Niehans, J. (1980): The Theory of Money. Baltimore: Johns Hopkins University Press.

RABIN, A.A. (2004): Monetary Theory. Northampton, MA: Edward Elgar.

RÖPKE, W. (1969): «The Fight against Inflationism.» In idem, Against the Tide, trans. Elizabeth Henderson. Chicago: Henry Regnery Company.

Rothbard, M.N. (1995): Classical Economics: An Austrian Perspective on the History of Economic Thought, Volume II. Brookfield, VT: Edward Elgar. 
- (2008): The Mystery of Banking. $2^{\text {nd }}$ ed. Auburn, AL: Ludwig von Mises Institute.

Salerno, J.T. (2010a): Money: Sound and Unsound. Auburn, AL: Ludwig von Mises Institute.

- (2010b): «White contra Mises on Fiduciary Media.» Mises Daily (May 14). Available at http:/ / mises.org/daily/4389.

- (2010c): «Selgin contra Horwitz and White on Mises's View of Fiduciary Media.» Mises Economics Blog (May 16). Available at http:/ / archive.mises.org/12724/selgin-contrahorwitz-and-white-on-misess-view-of-fiduciary-media /

Schumpeter, J.A. (1968): History of Economic Analysis. Ed. Elizabeth Boody Schumpeter. New York: Oxford University Press.

Selgin, G. (1988): The Theory of Free Banking: Money Supply under Competitive Note Issue. Totowa, NJ: Rowman\& Littlefield.

- (1997): Less Than Zero: The Case for a Falling Price Level in the Economy. London: Institute of Economic Affairs.

- (2010): Comment on Joseph T. Salerno, «Selgin contra Horwitz and White on Mises's View of Fiduciary Media.» Mises Economics Blog (May 18). Available at http:/ / archive. mises.org/12724/selgin-contra-horwitz-and-white-onmisess-view-of-fiduciary-media/\#comment-689126.

ToBin, J. (1987): "Commercial Banks as Creators of Money.» In idem, Essays In Economics: Volume 1: Macroeconomics. Cambridge, MA: The MIT Press, pp. 272-82.

VINER, J. (1937): Studies in the Theory of International Trade. New York: Harper \& Brothers Publishers.

White, L.H. (1986): «A Subjectivist Perspective on the Definition and Identification of Money.» In Israel M. Kirzner, ed., Subjectivism, Intelligibility and Economic Understanding: Essays in Honor of Ludwig M. Lachmann on His Eightieth Birthday. London: Macmillan Press, pp. 301-314.

- (1992): "Mises on Free Banking and Fractional Reserves.» In John W. Robbins and Mark Spangler, eds., A Man of Principle: Essays in Honor of Hans F. Sennholz. Grove City, PA: Grove City College Press. Pp. 517-529.

- (1999): The Theory of Monetary Institutions. Malden, MA: Blackwell Publishers. 
- (2010): «A Response to Salerno on Fiduciary Media.» Division of Labor (May 17). Available at http: / / divisionoflabour. com/archives/007130.php.

White, L.H. and SelgiN, G.A. (1989): «The Evolution of a Free Banking System.» Economic Inquiry. Vol. 25 (July 1987). Reprinted in Lawrence H. White, Competition and Currency: Essays on Free Banking and Money. New York: New York University Press, pp. 218-42.

Wu, CH. (2007): An Outline of International Price Theories. Auburn, AL: Ludwig von Mises Institute

YeAger, L.B. (1997): The Fluttering Veil: Essays on Monetary Equilibrium. Ed. George Selgin. Indianapolis: Liberty Fund. 